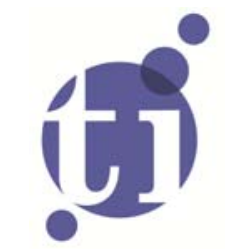

\title{
The Spatial Distribution of Creative Industries and Cultural Heritage in the Netherlands
}

\author{
Karima Kourtit \\ Jan Möhlmann \\ Peter Nijkamp* \\ Jan Rouwenda/*
}

* Tinbergen Institute, the Netherlands. 
Tinbergen Institute is the graduate school and research institute in economics of Erasmus University Rotterdam, the University of Amsterdam and VU University Amsterdam.

More TI discussion papers can be downloaded at http://www.tinbergen.nl

Tinbergen Institute has two locations:

Tinbergen Institute Amsterdam

Gustav Mahlerplein 117

1082 MS Amsterdam

The Netherlands

Tel.: +31(0)205251600

Tinbergen Institute Rotterdam

Burg. Oudlaan 50

3062 PA Rotterdam

The Netherlands

Tel.: +31(0)10 4088900

Fax: $+31(0) 104089031$

Duisenberg school of finance is a collaboration of the Dutch financial sector and universities, with the ambition to support innovative research and offer top quality academic education in core areas of finance.

DSF research papers can be downloaded at: http://www.dsf.nl/

Duisenberg school of finance

Gustav Mahlerplein 117

1082 MS Amsterdam

The Netherlands

Tel.: +31(0)20 5258579 
THE SPATIAL DISTRIBUTION OF CREATIVE INDUSTRIES AND CULTURAL HERITAGE IN THE NETHERLANDS

\author{
Karima Kourtit Jan Möhlmann Jeter Nijkamp* Jan Rouwendal \\ Department of Spatial Economics \\ VU University Amsterdam \\ *corresponding author: p.nijkamp@vu.nl
}

\begin{abstract}
This paper aims to investigate whether the spatial pattern of creative industries in the Netherlands has a relationship with the presence of cultural heritage or, in a more general sense, cultural capital. It first shows how the creative sector developed between $1994-2009$ in relation to other Dutch sectors. Additionally, it analyses the urban dimension of the creative industry by focussing on the four large urban agglomerations in the Netherlands. And finally, it addresses the question whether a relationship exists between the share of the creative industry and the stock of cultural heritage at the level of municipalities. The results show a positive correlation between local cultural heritage and the presence of the creative industry at the municipality level.
\end{abstract}

\title{
Acknowledgement
}

The authors wish to thank Maurice Kleijn for his assistance in the design of the maps in this paper. 


\section{The nexus of creativity and cultural heritage}

Our world houses a wealth of cultural heritage, interpreted here as a collection of physical and tangible artefacts that have an explicit and recognized connotation to the past of a place or area and may be seen as a self-identifying landmark for that place (see Nijkamp 2012, Nijkamp and Riganti 2009, Throsby 1999, Snowball 2008). Cultural heritage - an important component of cultural capital in a broader sense (Bourdieu 1986) - is a human-made capital asset that is in many cases characterized by many externalities, as it offers often unpaid services (e.g., quiet atmosphere, memory of the past, unique place identity, historical-cultural awareness, etc.) to visitors or the community at large. In addition, cultural heritage is mostly not reproducible, as it embodies unique or original historical, cultural, political or socioeconomic features or assets. Maintenance and expansion of this form of cultural capital is seen as a major challenge for urban development policy, not only from a preservation perspective, but also from a revenue-generating perspective (e.g., cultural tourism, attractiveness for creative classes) (see e.g. Bruinsma et al. 2009, Kourtit et al. 2011, Fusco Girard et al. 2012). Many large cities are characterized by an abundant presence of a great diversity of cultural heritage, which may be one of the reasons that people and firms move to these cities. This paper tests the hypothesis that creative people and firms are relatively strongly attracted to places with a rich cultural heritage.

The creative sector (Florida 2002, 2009) is particularly interesting, because creative people can be a driver of innovation and economic growth (see Section 3 for a definition of the creative sector). Creative minds can help to develop innovative ideas, to design new forms of technology or architecture, to experiment with new business models, to suggest new roads to sustainable development, and to act as fireplaces for many young people seeking for original concepts in a globalizing world. The urban creative economy needs an incubator and seedbed for unconventional pathways and roads less travelled, so as to create new competitive opportunities for innovations or new value-generating activities. Various seminal studies have been published in the past decade on the 'creativeness fashion', for instance, by Howkins (2001), Landry (2000), Peck (2005) and Scott (2006). Broader reviews on creative places and creative people are contained in Kloosterman (2005), Fusco Girard et al. (2012), Kourtit et al. (2011) and Camagni (2012) amongst others. Creative minds - in the sense of a collection of unconventional ideas, attitudes and behaviours - may foster innovation in terms of both ideas and practices. And therefore, they may act as effective growth engines in modern cities (see also Kourtit and Nijkamp 2013). 
It is likely that the relatively large presence of creative classes in many modern cities is not only the offspring of educational capital - in the sense of a spatial concentration of educational, training, and research facilities - in urban areas, but also of social capital (see Putnam 2000) ('communication as the source of creativeness') and cultural capital (Bourdieu 1986). Cultural capital - including cultural heritage - is assumed here to offer an innovative and open ambiance that stimulates creative thinking. Cultural capital refers to non-financial historical-social assets linked to the arts and culture in a way that combines a wide range of amenities, such as public provision for the arts and culture, cultural and creative activities, cultural participation, and visits to cultural and recreation services (museums, art galleries, theatres, cinemas, sports events).

It should be noted that the interaction between the creative sector and cultural capital in cities is a multi-faceted and complex research phenomenon that does not display a linear or unilateral relationship (see Wenting et al. 2011). Cities have a wealth of cultural facilities that may attract creative people, but at the same time the presence of a large creative class will also favour cultural performances and services in the city. It is clear that the city may act as a creative-cultural complex (see Section 2) which integrates artistic capital, knowledge capital, social capital, entertainment capital and economic capital (see also Glaeser 2011). But solid research on this complex research issue is still largely lacking. And therefore, the main aim of the present study is to analyse the relationship between the presence of the creative sector and cultural capital, in particular cultural heritage.

The paper is organized as follows. After the initial examination of the intricate relationship between the creative sector and the presence of cultural capital in Sector 2, Section 3 will describe the data that are used to test the above proposition in the Dutch context. Section 4 provides some descriptive statistics on the development of the creative sector in the Dutch economy, and gives particular attention to the creative sector in the four largest cities in The Netherlands. Section 5 presents the econometric estimation model that is used to estimate the relationship between the creative sector and cultural capital. The paper will be concluded with some retrospective and prospective remarks. 


\section{The creative-cultural urban complex}

New industrial initiatives (e.g., biotechnology, nanotechnology, aviation technology) tend to cluster in spatial concentrations. This phenomenon is known in the literature as industrial complexes (or industrial districts). This seems to hold true also for the creative industry.

In earlier research on spatial scale advantages in regional development the notion of industrial complexes played a central role (see e.g. Hoover 1937, Isard and Vietorisz 1955, Nijkamp 1972). An industrial complex was conceived of as a dynamic set of - technologically or economically interlinked - industrial activities located at the same place that through mutual linkages (e.g., mutual deliveries, knowledge exchange, joint use of common costminimizing transportation facilities, common use of marketing, communication or sales systems etc.) were able to benefit substantially from geographical scale externalities.

In subsequent research on emerging urban systems, the emphasis was increasingly placed on a variety of agglomeration externalities that were emerging in urban - often metropolitan agglomerations and that were held responsible for the persistent rise in urbanization rates all over the world (see for a review Nijkamp 2008). Various types of agglomeration externalities can be identified in modern urban systems, notably:

- MAR (Marshall-Arrow-Romer) externalities emerging from various agglomeration advantages, in particular scale, urbanization and infrastructural benefits (see e.g. Abreu et al. 2005).

- Social capital externalities in relation to social learning mechanisms in cities (see e.g. Bourdieu 1986, Putnam 2000), in particular the emergence of 'melting pot' advantages in case of urban cultural diversity (Jacobs 1961).

- Cluster advantages emerging from the mutual reinforcement of successful industrial activities in a given area (Porter 1998).

Modern cities - in combination with a high density of ICT presence and use - provide therefore the seedbed for intensive agglomeration externalities. For that reason, we may speak sometimes of an 'urban complex', as an analogous phenomenon to 'industrial complex'. As mentioned in Section 1, an important - though often neglected - constituent of a longstanding urban development is formed by urban cultural heritage. The presence of cultural heritage may sometimes hamper a flexible adjustment to new urban challenges and expansions, while sometimes also their sustainability and continuity may be endangered by rapid uncontrolled urban dynamics (see De Noronha Vaz et al. 2012). But they may also offer the basis for a 
solid long-term urban stability, in particular, in case of cultural visits and tourism (see Fusco Girard and Nijkamp 2009). In addition, they may create interesting 'image' externalities which may have a positive effect on the value of urban real estate (see Nijkamp 2012) or on the attractiveness of the city for innovative or creative minds. Especially the latter phenomenon, viz. the interface between the creative industry and cultural heritage in the city, deserves more empirical investigation.

In the literature, creative and cultural industries are sometimes used in a mixed form. In this paper we use a broad definition of the creative industry, following Rutten et al. (2004). ${ }^{1}$ Their definition also includes some economic activities that can fall under a definition of cultural industries as well. It is noteworthy that different views on the intricate relationship between cultural heritage and creative industries are voiced:

- Innovative or novel ideas may flourish best in an appropriate urban climate with a sense of historical authenticity, in particular cultural heritage. Jane Jacobs (1961) even argues that new ideas are born in old buildings. Consequently, industrial heritage (such as brownfields in the city) may attract creative talent. This proposition may indeed seem plausible, if empty - and hence cheap - buildings in culturally attractive areas act as incubators for creativeness, but such amenities are by no means sufficient. This is illustrated by the Detroit case, where empty factories have not induced an influx of creative minds. Clearly, a culturally-rich city may attract creative and social capital, which may lead to more new firm formation.

- The abundant presence of urban cultural heritage - for instance, in the form of a monumental historical inner-city or an attractive cultural urban 'ambiance' - contributes to an innovative urban climate that favours creative minds. These creative minds may be employees, self-employed or entrepreneurs, but they may also comprise visitors. Their presence may need the availability of - and access to - both production facilities and consumer amenities. In this paper, we will test this hypothesis by relating the share of creative industries in municipalities to the presence of cultural heritage.

\footnotetext{
${ }^{1}$ We extended the classification of Rutten et al. (2004) with distribution of motion pictures (SBI 9212).
} 


\section{Data on creative sectors and cultural capital}

Our empirical analysis is based on data on the level of municipalities. We used firm-level data in order to determine the share of creative firms in each municipality. We determined these shares based on the number of firms as well as on the size of employment. For the definition of the creative industry, we use the classification created by TNO (see Rutten et al. 2004). This classification contains three types of creative firms, viz. arts, media and entertainment, and creative business services. Table 1 shows which economic activities are classified in these three groups.

Table 1. The classification of the creative industries

\begin{tabular}{|c|c|c|}
\hline \multirow[t]{2}{*}{ Branch } & \multicolumn{2}{|r|}{ Standard Industrial Classification (SBI) } \\
\hline & SBI-1993 & Description \\
\hline \multirow[t]{7}{*}{ Art } & 92311 & Performing arts \\
\hline & 92312 & Production of stage productions \\
\hline & 92313 & Other artistic creation \\
\hline & 92321 & Theatres \\
\hline & 92323 & Support activities for artists \\
\hline & 92521 & Art galleries \\
\hline & 92522 & Museums \\
\hline \multirow[t]{15}{*}{ Media } & 2211 & Publishing of books \\
\hline & 2212 & Publishing of newspapers \\
\hline & 2213 & Publishing of magazines \\
\hline & 2214 & Publishing of sound recordings \\
\hline & 2215 & Other publishing \\
\hline & 74811 & Photography \\
\hline & 92111 & Motion picture production (not for television) \\
\hline & 92112 & Support activities for motion picture production \\
\hline & 92201 & Radio and television broadcasting \\
\hline & 92202 & Production of programmes for radio and television \\
\hline & 92203 & Support activities for radio en television \\
\hline & 9212 & Distribution of motion pictures \\
\hline & 9213 & Cinemas \\
\hline & 92343 & Other entertainment \\
\hline & 9240 & Press- and news agencies; journalists \\
\hline \multirow[t]{5}{*}{ Creative Business Services } & 74201 & Architecture and technical designs \\
\hline & 74202 & Technical design and consultancy for cities and landscape \\
\hline & 74401 & Design and consultancy for advertising \\
\hline & 74402 & Other advertising services \\
\hline & 74875 & Interior and fashion design \\
\hline
\end{tabular}

Note: based on the classification by Rutten et al. (2004), extended with distribution of motion pictures (SBI 9212).

We obtained the main economic activity of all Dutch firms from the Dutch central firm registry (ABR) from Statistics Netherlands. Besides the main economic activity, this registry also contains the location of the headquarters of the firm and an estimate of the number of full time equivalents (fte's) that work in the firm. We only included the firms that were registered as active at the last day of the year. We used the economic activity and the location of the headquarters of each firm to create an indicator at the municipality level for the number of firms that are active in the creative industry and its subsectors. In the same way we created an 
indicator for the number of fte's in the creative industry. ${ }^{2}$ This allows us to trace not only the development of the creative industry vis-à-vis the remaining other industries in The Netherlands, but also to explore whether the larger cities act as attraction forces for creative minds.

The next step of our analysis is to explore the relationship between cultural capital in the municipality and the presence (or growth) of creative branches in the city. As a proxy for cultural capital we use the number of theatres, museums and cinemas and the number of state monuments. In addition to these variables we include the number of inhabitants and the average price of a standard house as proxies for agglomeration. The average prices of a standard house were estimated by estimating an hedonic price model on the data from the NVM. $^{3}$ Table 2 gives an overview of the data sources on the proxies for cultural capital and agglomeration.

Table 2. Data sources

\begin{tabular}{llc}
\hline Variable & Source & Year \\
\hline Number of theatres + museums + cinemas & ABF Research & 2006 \\
Number of state monuments & Rijksdienst voor het Cultureel Erfgoed (RCE) & 2008 \\
Number of inhabitants & Centraal Bureau voor de Statistiek (CBS) & 2007 \\
House prices & Nederlandse Vereniging van Makelaars (NVM) & 2007 \\
\hline
\end{tabular}

Figure 1 shows the shares of the creative industry in 1996 and 2009 and the number of state monuments at the level of COROP regions. ${ }^{4}$ The shares of the creative industry in the left panel are based on the number of firms. In the right panel, these shares are based on employment. These figures show a concentration of state monuments in the western part of the Netherlands. The creative industry is also over-represented in this part of The Netherlands. This could indicate a correlation between these two variables, which is further investigated in Section 5 .

\footnotetext{
${ }^{2}$ With this method, all employment of a firm is allocated to the location of its headquarters, which is not the case if a firm has multiple plants or offices. Therefore, this indicator should not be interpreted as the actual sectoral employment in the municipalities concerned.

${ }^{3}$ The hedonic price model was estimated by Mark van Duijn.

${ }^{4}$ A COROP region is a NUTS-3 regional area that consists several adjacent municipalities (NUTS-4). There are 40 COROP regions in the Netherlands.
} 
Figure 1. Share of the creative industries in 1996 and 2009 and Dutch state monuments per COROP region in the Netherlands.
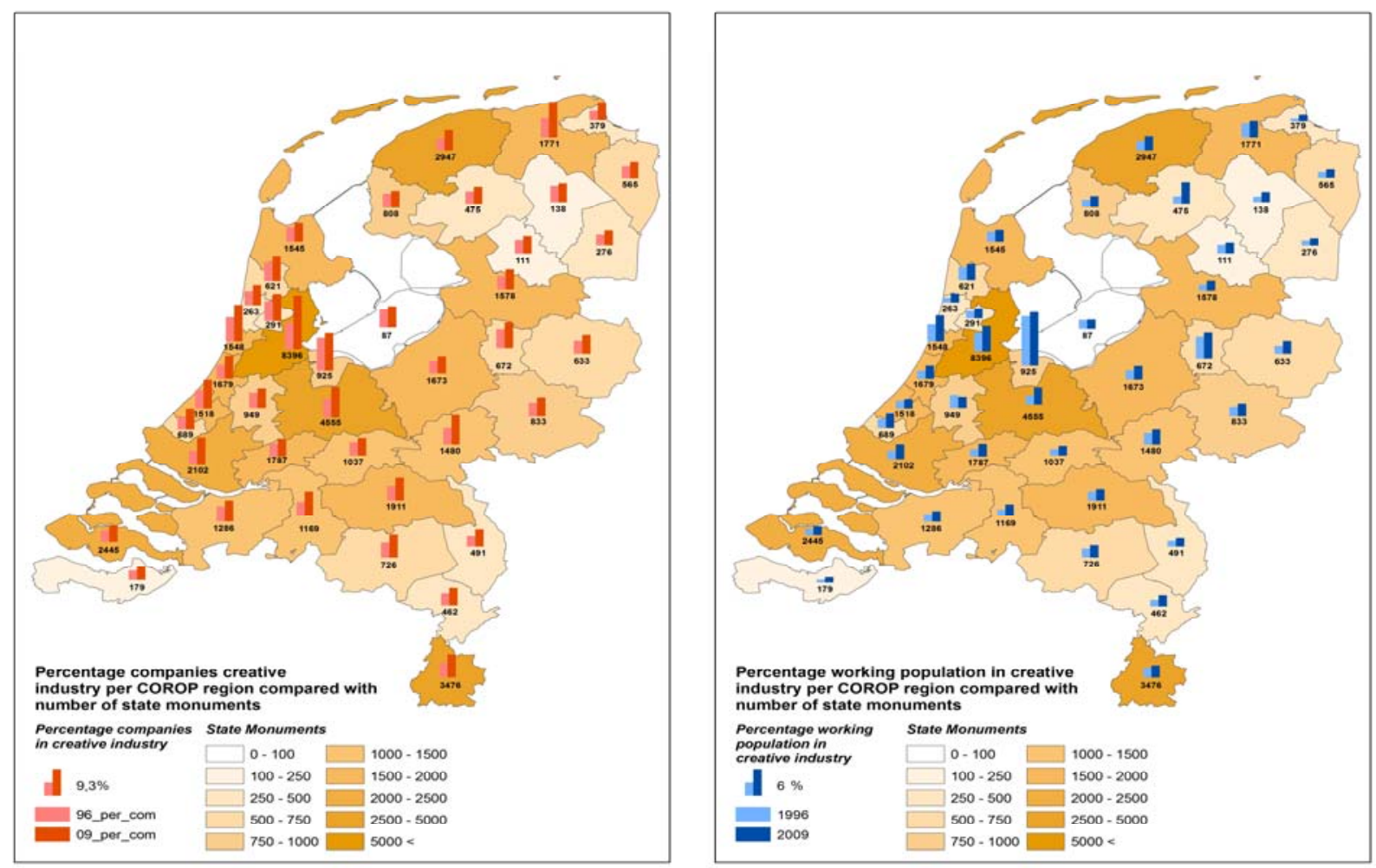

\section{Background information}

This section offers some stylized facts on the size of the three groups of creative firms in the Dutch economy. It will show how the share of the creative industry developed between 1994 and 2009. This is done for The Netherlands and also for the four largest cities in the Netherlands, viz. Amsterdam, Rotterdam, The Hague and Utrecht.

Table 3 shows the shares of the creative industries in the total economy of the Netherlands, in terms of the number of firms and the number of fte's. This shows that the relative importance of the creative industries is modest, but has increased significantly between 1994 and 2009. This applies to the number of firms as well as to the employment in this sector. 
Table 3. Shares the creative sector (1994-2009)

\begin{tabular}{l|ccc|c}
\hline & Arts & Media & $\begin{array}{c}\text { Creative } \\
\text { business } \\
\text { services }\end{array}$ & $\begin{array}{c}\text { Total creative } \\
\text { industry }\end{array}$ \\
\hline Share in number of firms (1994) & $0.9 \%$ & $1.4 \%$ & $2.2 \%$ & $4.5 \%$ \\
Share in number of firms (2009) & $3.1 \%$ & $2.3 \%$ & $3.9 \%$ & $9.2 \%$ \\
Share in fte's (1994) & $0.2 \%$ & $0.9 \%$ & $0.9 \%$ & $2.0 \%$ \\
Share in fte's (2009) & $0.8 \%$ & $1.0 \%$ & $1.6 \%$ & $3.4 \%$ \\
\hline
\end{tabular}

It also turns out that firms in the creative sector are on average smaller than firms in other sectors: in 2009 their share in the number of firms was 9.2 percent, but their share in employment was only 3.4 percent. Nevertheless, the total employment in the creative sector increased relatively strong between 1994 and 2009. The employment associated with creative firms has increased from about 105,000 fte in 1994 to about 253,000 fte in 2009, which implies an average annual growth of over six percent.

Next, we consider the growth of the creative industry relative to that of other industries in the four largest cities in the Netherlands. The first column of Table 4 shows the growth of the number in the total Dutch economy (excluding the creative firms) and the second column shows the growth of the number of creative firms. It is clear that the creative industry shows a much faster growth ( 7.3 percent) than the average of the other sectors (1.9 percent). The last three columns of Table 4 illustrate that there are substantial differences between the subsectors of the creative industry, but also that all three of them grow much faster than the non-creative sectors. The growth rate is highest for the art sector with an average annual growth rate in the number of firms of 11.3 percent, followed by creative business services $(6.2$ percent), and the media (5.5 percent). The creative sector grows even faster in the four largest agglomerations, while the pattern of the subsectors remains similar to the national pattern, with art growing the fastest, followed by creative business services, and the media.

Table 4. Average annual growth in the number of firms 1994-2009 (\%)

\begin{tabular}{|c|c|c|c|c|c|}
\hline & All other sectors & $\begin{array}{l}\text { Creative } \\
\text { industry }\end{array}$ & $\begin{array}{c}\text { Arts } \\
\text { (i) }\end{array}$ & $\begin{array}{l}\text { Media } \\
\text { (ii) }\end{array}$ & $\begin{array}{c}\text { Creative } \\
\text { business } \\
\text { services } \\
\text { (iii) }\end{array}$ \\
\hline The Netherlands & 1.9 & 7.3 & 11.3 & 5.5 & 6.2 \\
\hline Amsterdam & 0.2 & 10.4 & 14.5 & 7.8 & 9.7 \\
\hline Rotterdam & 0.1 & 9.0 & 14.5 & 6.6 & 7.2 \\
\hline The Hague & 1.8 & 7.8 & 13.1 & 5.0 & 6.2 \\
\hline Utrecht & 3.3 & 10.9 & 13.4 & 10.0 & 9.6 \\
\hline
\end{tabular}


Table 5 shows the growth rates for employment instead of the number of firms. The main pattern is similar to that of the number of firms, but there are also some interesting differences. For the creative industry, the growth rate of employment is smaller than that of the number of firms, whereas for the rest of the economy the reverse is true. This indicates that the growth of the creative industry is mainly driven by the entry of new firms. These growth rates imply that the average employment per firm has decreased in the creative industry and increased in the other industries. For the three creative subsectors we see that in the subsector arts and creative business services, the growth of employment is almost equal to the growth in the number of firms, whereas for the subsector media the growth in employment is much smaller.

Table 5. Growth in employment 1994-2009 (\%)

\begin{tabular}{|c|c|c|c|c|c|}
\hline & All other sectors & $\begin{array}{l}\text { Creative } \\
\text { industry }\end{array}$ & $\begin{array}{l}\text { Arts } \\
\text { (i) }\end{array}$ & $\begin{array}{c}\text { Media } \\
\text { (ii) }\end{array}$ & $\begin{array}{c}\text { Creative } \\
\text { business } \\
\text { services } \\
\text { (iii) } \\
\end{array}$ \\
\hline The Netherlands & 2.2 & 6.1 & 10.8 & 3.3 & 6.6 \\
\hline Amsterdam & 3.0 & 6.9 & 10.9 & 5.2 & 6.6 \\
\hline Rotterdam & 1.1 & 7.3 & 15.6 & 2.4 & 6.1 \\
\hline The Hague & 2.5 & 6.3 & 8.9 & 4.4 & 5.7 \\
\hline Utrecht & 2.8 & 10.6 & 16.4 & 6.6 & 10.6 \\
\hline
\end{tabular}

Figure 2 illustrates that the higher growth of employment in the creative industry is caused by a higher growth of the number of firms. This figure shows the development of the number of firms (left axis) as an index $(1994=100)$ as well as the development of the average fte per firm (right axis). In the period 1994-2009, the number of firms in the creative industry has almost tripled, while the increase in the number of firms in the other sectors was about 33 percent. The figure also confirms that firms in the creative industry are on average much smaller than firms in other sectors. In 2009, the average employment generated by firms in the creative industry was about $2.3 \mathrm{fte}$, while firms in other sectors employed on average $6.7 \mathrm{fte}$.

The strong performance of the creative industry and creative people in the four large urban agglomerations in the Netherlands could be associated with the presence of cultural heritage, as these cities - Rotterdam being an exception - are important concentrations of cultural heritage, and in a more general sense, cultural capital. However, there may be many other reasons than cultural heritage that attract creative firms and people to those areas, and therefore, strict causalities on the impact of cultural assets should only be inferred with great caution. The next section further explores the potential relationship between cultural capital and the share of the creative industry at the municipality level. 
Figure 2. Number of firms (left axis, $1994=100)$ and fte's per firm (right axis)

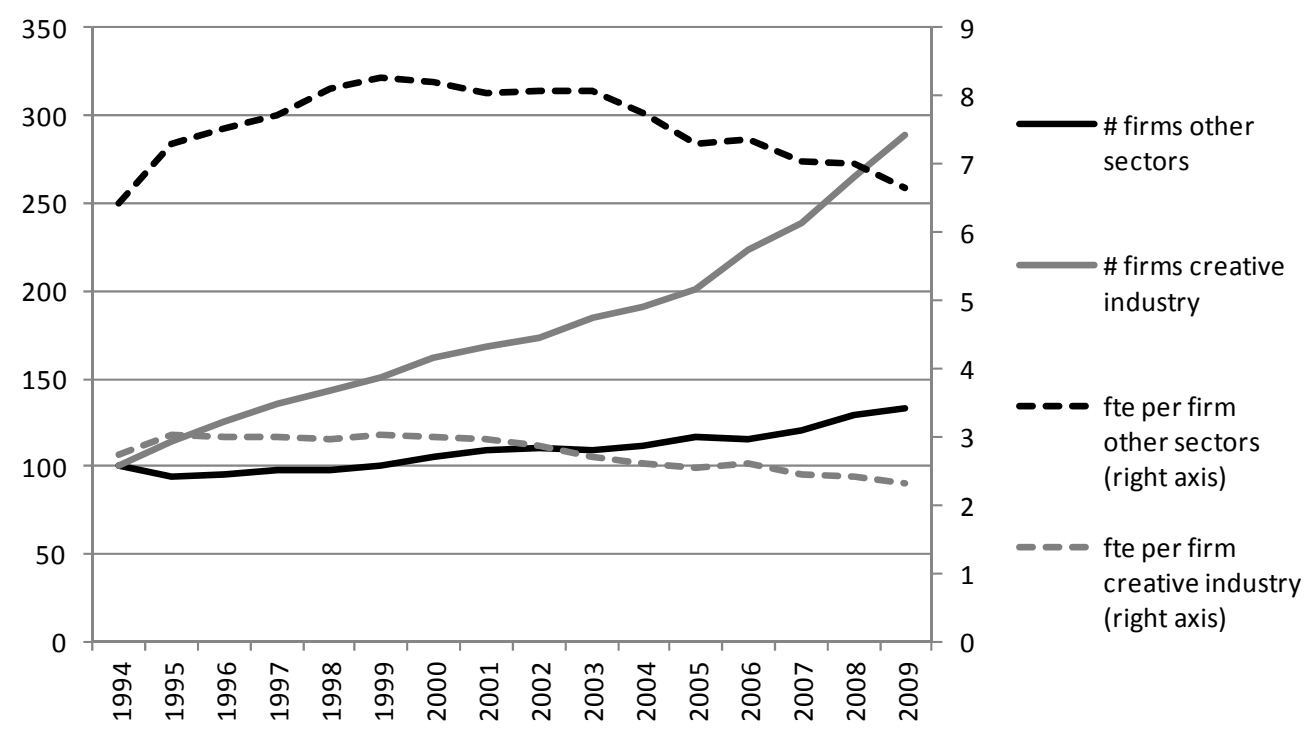

\section{Estimation results for creative firms and cultural heritage}

The theoretical framework of the empirical model rests on the proposition that an abundance - or relatively high presence - of local cultural heritage acts as a magnet for creative minds. To investigate the relationship between cultural heritage and the creative industry in greater detail, we performed a regression analysis on the shares of the creative industry and its three above-mentioned subsectors at the level of Dutch municipalities. This has been done for both the share of creative firms and the share of their employment. We used the following model:

$$
S_{i}=\alpha+\beta_{1} \ln (\text { inhabitants })_{i}+\beta_{2} \ln (\text { avg house price })_{i}+\beta_{3}\left(\frac{\text { cult }}{\text { inhabitants }}\right)_{i}+\beta_{4}\left(\frac{\text { rmon }}{\text { inhabitants }}\right)_{i}+\varepsilon_{i}
$$

where $S_{i}$ stands for the share of the creative industry or one of its subgroups in municipality $i$, in terms of the number of firms or in terms of the employment. We used the logarithm of the number of inhabitants and the logarithm of the price of a standard house as proxies for agglomeration, since house prices tend to be higher in more dense areas. The variable cult represents the number of theatres, museums and cinemas while the variable rmon represents the number of state monuments. We divided these two indicators for cultural capital by the number of inhabitants to correct for the size of municipalities. Therefore, these variables can be interpreted as the density of cultural capital. The estimations are used to test whether the indicators of cultural capital offer additional explanatory power for the share of creative firms in municipalities. 
Some remarks may be made on the specification of the above equation. Theoretically, different specifications could have been used, but the data constraints meant a serious limitation for our model..$^{5}$ Thus, some variables are at best a proxy of a real-world phenomenon to be measured. Table 6 shows the results for the year 2009. The results for other years appear to be largely similar, but will not be shown here in order to save space.

Table 6. Share of firms in creative industry (2009)

\begin{tabular}{|c|c|c|c|c|}
\hline & Creative industry & $\begin{array}{c}\text { Arts } \\
\text { (i) }\end{array}$ & $\begin{array}{c}\text { Media } \\
\text { (ii) }\end{array}$ & $\begin{array}{c}\text { Creative Business } \\
\text { Services (iii) } \\
\end{array}$ \\
\hline \multirow[t]{2}{*}{ Constant } & $-0.50^{k * k}$ & $-0.11^{\text {***3* }}$ & $-0.17^{* * * k}$ & $-0.22^{* 3 *}$ \\
\hline & $(0.05)$ & $(0.02)$ & $(0.02)$ & $(0.02)$ \\
\hline \multirow[t]{2}{*}{$\ln$ (number of inhabitants) } & $0.014^{* * * *}$ & $0.006^{* * * *}$ & $0.0036^{* * *}$ & $0.005^{* * *}$ \\
\hline & $(0.001)$ & $(0.001)$ & $(0.0004)$ & $(0.001)$ \\
\hline \multirow[t]{2}{*}{$\ln$ (house price of a standard house) } & $0.034^{* * * *}$ & $0.005^{* * * *}$ & $0.012^{* * * *}$ & $0.016^{* * * *}$ \\
\hline & $(0.004)$ & $(0.002)$ & $(0.001)$ & $(0.002)$ \\
\hline Number of theatres, museums and & 10.11 & $12.33^{* * *}$ & 3.18 & -5.40 \\
\hline cinemas per inhabitant & $(9.51)$ & $(4.26)$ & $(3.23)$ & $(3.70)$ \\
\hline Number of state monuments per & $1.29^{* * * *}$ & $0.68^{* * *}$ & $0.36^{* * *}$ & $0.244^{* * *}$ \\
\hline inhabitant & $(0.22)$ & $(0.10)$ & $(0.07)$ & $(0.09)$ \\
\hline Observations & 436 & 436 & 436 & 436 \\
\hline$R^{2}$ & 0.33 & 0.26 & 0.27 & 0.34 \\
\hline Method & OLS & OLS & OLS & OLS \\
\hline
\end{tabular}

Note: standard deviations in brackets; stars indicate significance levels of $0.01^{* * *}, 0.05^{* *}$ and $0.10^{*}$.

Tables 6 and 7 show that the coefficient for the logarithm of the average house price is significant and positive for all estimations. The logarithm of the number of inhabitants is significant and positive for all sectors in the estimations on the share based on number of firms, but not in the estimations based on the share of employment. This suggests that the larger municipalities tend to attract many small firms from the creative industry.

Table 7. Share of employment in creative industry (2009)

\begin{tabular}{|c|c|c|c|c|}
\hline & Creative industry & $\begin{array}{l}\text { Arts } \\
\text { (i) }\end{array}$ & $\begin{array}{l}\text { Media } \\
\text { (ii) }\end{array}$ & $\begin{array}{c}\text { Creative Business } \\
\text { Services (iii) }\end{array}$ \\
\hline \multirow[t]{2}{*}{ Constant } & $-0.32^{* * *+1}$ & $-0.05^{* * * 4}$ & $-0.12^{* * * *}$ & $-0.16^{* * *}$ \\
\hline & $(0.05)$ & $(0.01)$ & $(0.03)$ & $(0.04)$ \\
\hline \multirow[t]{2}{*}{$\ln$ (number of inhabitants) } & -0.00002 & -0.0002 & $0.0012^{* *}$ & -0.0011 \\
\hline & $(0.001)$ & $(0.0003)$ & $(0.0006)$ & $(0.0008)$ \\
\hline \multirow[t]{2}{*}{$\ln$ (house price of a standard house) } & $0.029^{* * *}$ & $0.004^{* * *}$ & $0.009^{* * *}$ & $0.015^{* * *}$ \\
\hline & $(0.004)$ & $(0.001)$ & $(0.002)$ & $(0.003)$ \\
\hline Number of theatres, museums and & 8.14 & $9.81^{* * *}$ & 4.36 & -6.03 \\
\hline cinemas per inhabitant & $(9.025)$ & $(2.35)$ & $(4.50)$ & $(6.41)$ \\
\hline Number of state monuments per & $0.37^{*}$ & $0.26^{* * * *}$ & 0.14 & -0.03 \\
\hline inhabitant & $(0.21)$ & $(0.05)$ & $(0.10)$ & $(0.15)$ \\
\hline Observations & 436 & 436 & 436 & 436 \\
\hline$R^{2}$ & 0.12 & 0.18 & 0.06 & 0.07 \\
\hline Method & OLS & OLS & OLS & OLS \\
\hline
\end{tabular}

Note: standard deviations in brackets; stars indicate significance levels of $0.01^{* * *}, 0.05^{* *}$ and $0.10^{*}$.

\footnotetext{
${ }^{5}$ As an alternative specification, we have also included the number of restaurants and bars, as a proxy for social capital. This variable was usually statistically insignificant, and did not have much effect on the coefficients for cultural heritage.
} 
Additionally, these results show that the share of creative firms in the total number of firms is positively related to the number of Dutch state monuments per inhabitant for all creative subsectors. The number of museums, theatres and cinemas per inhabitant is only positively related to the share of the art sector, while it is statistically insignificant for the other sectors. For the share of creative sectors in employment, both indicators for cultural capital are only significant for the art sector. This shows that cultural capital seems to be particularly important for firms that are active in the art sector. The other creative sectors, media and creative business services, only show a positive relationship with Dutch state monuments when looking at the number of firms.

Table 8. Change in the share of firms in creative industry (1994-2009)

\begin{tabular}{|c|c|c|c|c|}
\hline & Creative industry & $\begin{array}{l}\text { Arts } \\
\text { (i) }\end{array}$ & $\begin{array}{c}\text { Media } \\
\text { (ii) }\end{array}$ & $\begin{array}{c}\text { Creative Business } \\
\text { Services (iii) }\end{array}$ \\
\hline \multirow[t]{2}{*}{ Constant } & $-0.22^{* \pi * \pi}$ & $-0.07^{3 \% \pi}$ & $-0.05^{3 \pi * \pi}$ & $-0.10^{3 m \%}$ \\
\hline & $(0.04)$ & $(0.02)$ & $(0.01)$ & $(0.02)$ \\
\hline \multirow[t]{2}{*}{$\ln$ (number of inhabitants) } & $0.0104^{* * *}$ & $0.0054^{* * *}$ & $0.0015^{* * *}$ & $0.0035^{* * *}$ \\
\hline & $(0.0010)$ & $(0.0005)$ & $(0.0003)$ & $(0.0005)$ \\
\hline \multirow[t]{2}{*}{$\ln$ (house price of a standard house) } & $0.012^{* * *}$ & 0.002 & $0.003^{* * *}$ & $0.006^{* * * *}$ \\
\hline & $(0.004)$ & $(0.002)$ & $(0.001)$ & $(0.002)$ \\
\hline Number of theatres, museums and & $25.10^{* * *}$ & $14.50^{* * *}$ & 4.54 & 6.06 \\
\hline cinemas per inhabitant & $(8.92)$ & $(4.63)$ & $(2.97)$ & (3.99) \\
\hline Number of state monuments per & $0.69^{* * * *}$ & $0.48^{* * * *}$ & 0.09 & 0.12 \\
\hline inhabitant & $(0.18)$ & $(0.09)$ & $(0.06)$ & $(0.08)$ \\
\hline Observations & 370 & 370 & 370 & 370 \\
\hline$R^{2}$ & 0.26 & 0.25 & 0.08 & 0.17 \\
\hline Method & OLS & OLS & OLS & OLS \\
\hline
\end{tabular}

Note: standard deviations in brackets; stars indicate significance levels of $0.01^{* * *}, 0.05^{* *}$ and $0.10^{*}$.

In order to investigate the relationship between the growth of the creative sector and the presence of cultural capital, we have also regressed the change in the share of creative firms on the same set of explanatory variables. This allows us to determine whether the creative sector will grow faster than the non-creative sector in municipalities with relatively much cultural capital. The results are presented in Tables 8 and 9. The number of observations is lower, because we only included municipalities that existed in 1994 as well as in 2009. 
Table 9. Change in the share of employment in creative industry (1994-2009)

\begin{tabular}{|c|c|c|c|c|}
\hline & Creative industry & $\begin{array}{l}\text { Arts } \\
\text { (i) }\end{array}$ & $\begin{array}{c}\text { Media } \\
\text { (ii) }\end{array}$ & $\begin{array}{c}\text { Creative Business } \\
\text { Services (iii) }\end{array}$ \\
\hline \multirow[t]{2}{*}{ Constant } & $-0.12^{* *}$ & $-0.03^{* *}$ & $-0.04^{* * *}$ & -0.04 \\
\hline & $(0.05)$ & $(0.01)$ & $(0.02)$ & $(0.04)$ \\
\hline \multirow[t]{2}{*}{$\ln$ (number of inhabitants) } & $-0.0023^{*}$ & -0.0002 & $-0.0015^{* * *}$ & -0.0006 \\
\hline & $(0.0011)$ & $(0.0003)$ & $(0.0005)$ & $(0.0009)$ \\
\hline \multirow[t]{2}{*}{$\ln$ (house price of a standard house) } & $0.012^{* * *}$ & $0.003^{* * * *}$ & $0.005^{* * *}$ & 0.005 \\
\hline & $(0.004)$ & $(0.001)$ & $(0.002)$ & $(0.003)$ \\
\hline Number of theatres, museums and & 14.97 & $6.58^{* *}$ & $8.86^{* *}$ & -0.48 \\
\hline cinemas per inhabitant & $(9.78)$ & $(2.67)$ & $(3.99)$ & $(7.51)$ \\
\hline Number of state monuments per & 0.29 & $0.19^{* * * *}$ & 0.10 & 0.003 \\
\hline inhabitant & $(0.20)$ & $(0.05)$ & $(0.08)$ & $(0.151)$ \\
\hline Observations & 370 & 370 & 370 & 370 \\
\hline$R^{2}$ & 0.06 & 0.09 & 0.08 & 0.01 \\
\hline Method & OLS & OLS & OLS & OLS \\
\hline
\end{tabular}

Note: standard deviations in brackets; stars indicate significance levels of $0.01^{* * *}, 0.05^{* *}$ and $0.10^{*}$.

These results are somewhat similar to those found for the level of the shares. Again, the indicators for agglomeration are positive and significant for the share based on the number of firms. The logarithm of the average house price is positive and significant for the share of employment, except for the creative business services. The logarithm of inhabitants is negative for the share of media in employment, while it is statistically insignificant for the other subsectors. This implies that employment in media grows slightly slower than other sectors in the larger municipalities.

The cultural capital variables have a positive and significant relationship with the growth of the share of the art sector, both in terms of the number of firms as well as for employment. This implies that in municipalities with relatively much cultural capital, the art sector grows faster compared to the other sectors. The growth rates of the other creative sectors, media and creative business services, do not seem to have a significant relationship with cultural capital, except for the employment of the media sector.

These results demonstrate that on the level of the municipality, cultural capital such as Dutch state monuments can play a role in both the level as well as the change of the share of creative firms and employment in creative firms. This relationship is mainly caused by the subsector arts, and is less prominent in the other creative subsectors. 


\section{Concluding remarks}

The creative industry - and its manifold subsectors - has prompted in recent years a widespread interest in the drivers and impacts of this sector (see also Jones-Evans and Klofsten 1997, Bommer and Jalajas 2002). Urban agglomerations offer a great diversity in seedbed conditions for a flourishing creative industry. Our research has explored the relationship between urban cultural capital and the level and growth of various branches of the creative sector, with a particular view to urban agglomerations in the Netherlands. The creative sector in the Netherlands appears to grow - in terms of both the number of firms and the number of jobs - significantly faster than other industries over the period 1994-2009. The sector employed about 2 percent of the employed population in 1994 and 3.2 percent in 2009. This seems to be mainly driven by the entry of new firms. Additionally, within the creative sector, the subsector arts appears to be a fast grower in comparison to the subsector media and the subsector creative business services.

The creative industry appears to be mainly concentrated - and to have the highest growth rates - in urban areas. This suggests that agglomeration externalities may be an essential element here. Additionally, we find a positive relationship between the share of creative firms and cultural capital. This applies to both the level of this share as well as its growth. This holds in particular for the arts sector, and less for the media sector and the creative business services. These results suggest a relationship between cultural heritage and the creative industries, but further research is necessary to determine whether there is a causal relationship. 


\section{References}

Abreu, M., H.L.F. de Groot and R.J.G.M. Florax (2005), Space and Growth: A Survey of Empirical Evidence and Methods, Région et Développement, 21, pp. 13-44.

Bommer, M, and D. Jalajas (2002), The Innovation Work Environment of High-Tech SMEs in the USA and Canada, $R \& D$ Management, 32, pp. 379-386.

Bourdieu, P. (1986), The Forms of Capital, in: J. Richardson (ed.), Handbook of Theory and Research for the Sociology of Education, Greenwood, New York.

Bruinsma F.R., K. Kourtit and P. Nijkamp (2009), Tourism, Culture and E-Services: Evaluation of EServices Packages, Innovative Marketing, 5, pp. 32-50.

Camagni, R. (2012), Creativity, Culture and Urban Milieux, in: L. Fusco Girard, T. Baycan and P. Nijkamp (eds.), Sustainable City and Creativity, Ashgate, Aldershot.

De Noronha Vaz, E., P. Nijkamp, M. Painho and M. Caetano (2012), A Multi-Scenario Forecast of Urban Change: A Study on Urban Growth in the Algarve, Landscape and Urban Planning, 104, pp. 201-211.

Florida, R. (2002), The Rise of the Creative Class - and How it is Transforming Work, Leisure, Community and Everyday Life, Basic Books, New York.

Florida, R. (2009), Entrepreneurship, Creativity and Regional Economic Growth, in: D.M. Hart (ed.), The Emergence of Entrepreneurship Policy, Cambridge University Press, Cambridge.

Fusco Girard, L. and P. Nijkamp (eds.) (2009), Cultural Tourism and Sustainable Local Development, Ashgate, Aldershot.

Fusco Girard, L., T. Baycan and P. Nijkamp (eds.) (2012), Sustainable City and Creativity, Ashgate, Aldershot.

Glaeser, E.L. (2011), Triumph of the City: How Our Greatest Invention Makes Us Richer, Smarter, Greener, Healthier and Happier, The Penguin Press, New York.

Hoover, E.M. (1937), Location Theory and the Shoe and Leather Industries, Harvard University Press, Cambridge MA.

Howkins, J. (2001), The Creative Economy: How People Make Money from Ideas, Allan Lane, London.

Isard, W. and T. Vietorisz (1955), Industrial Complex Analysis and Regional Development, Papers in Regional Science, 1, 227-247.

Jacobs, J. (1961), The Death and Life of Great American Cities, Random House, New York.

Jones-Evans, D. and M. Klofsten (1997), Universities and Local Economic Development: The Case of Linköping, European Planning Studies, 5, pp. 77-93.

Kloosterman, R. (2005), The Creative Hype, in: S. Franke and E. Verhagen (eds.), Creativity and the City: How the Creative Economy Changes the City, NAi Publishers, Rotterdam.

Kourtit, K. and P. Nijkamp (2013), The Use of Visual Decision Support Tools in an Interactive Stakeholder Analysis - Old Ports as New Magnets for Creative Urban Development, Sustainability, 5, pp. 4379-4405.

Kourtit, K., P. Nijkamp, S. Lowik, F van Vught and P. Vulto (2011), From Islands of Innovation to Creative Hotspots, Journal of Regional Science Policy and Practice, 3, pp. 145-161.

Landry, C. (2000), The Creative City: A Toolkit for Urban Innovators, Earthscan, London.

Nijkamp, P. (1972), Planning of Industrial Complexes by Means of Geometric Programming, Rotterdam University Press, Rotterdam.

Nijkamp, P. (2008), XXQ Factors for Sustainable Urban Development: A Systems Economics View, Romanian Journal of Regional Science, 2, pp. 1-34. 
Nijkamp, P. (2012), Economic Valuation of Cultural Heritage, in: G. Licciardi and R. Amirtahmasebi (eds.), The Economics of Uniqueness, The World Bank, Washington DC.

Nijkamp, P. and P. Riganti (2009), Valuing Urban Cultural Heritage, in: L. Fusco Girard and P. Nijkamp (eds.), Cultural Tourism and Sustainable Local Development, Ashgate, Aldershot.

Peck, J. (2005), Struggling with the Creative Class, International Journal of Urban and Regional Research, 29, pp. 740-770.

Porter, M.E. (1998), Clusters and the New Economics of Competition, Harvard Business Review, 76, pp. 77-90.

Putnam, R.D. (2000), Bowling Alone: The Collapse and Revival of American Community, Simon \& Schuster, New York.

Rutten, P., W. Manshanden, J. Muskens and O. Koops (2004), De Creatieve Industrie in Amsterdam en de Regio, TNO, Delft.

Scott, A.J. (2006), Creative Cities: Conceptual Issues and Policy Questions, Journal of Urban Affairs, 28, pp. 1-17.

Snowball, J.D. (2008), Measuring the Value of Culture: Methods and Examples in Cultural Economics, Springer-Verlag, Berlin.

Throsby, D. (1999), Cultural Capital, Journal of Cultural Economics, 23, pp. 3-12.

Wenting, R., O. Atzema and K. Frenken (2011), Urban Amenities and Agglomeration Economies? The Locational Behaviour and Economic Success of Dutch Fashion Design Entrepreneurs, Urban Studies, 48, pp. 1333-1352. 